\title{
BEARING CAPACITY OF DAMAGED REINFORCED CONCRETE BEAMS STRENGTHENED WITH METAL CASING
}

\author{
Irina Karpiuk ${ }^{a, *}$, Denis Danilenko $^{b}$, VAsyl Karpiuk $^{b}$, Anna Danilenko $^{c}$, \\ TATIANA LyASHENKO ${ }^{d}$ \\ ${ }^{a}$ Odessa State Academy of Civil Engineering and Architecture, Institute of Hydraulic Engineering and Civil \\ Engineering, Didrikhson St. 4, 65029 Odessa, Ukraine \\ ${ }^{b}$ Odessa State Academy of Civil Engineering and Architecture, Engineering-building institute, st. Didrikhson 4, \\ 65029 Odessa, Ukraine \\ ${ }^{c}$ Odessa State Academy of Civil Engineering and Architecture, Construction and Technological Institute, st. \\ Didrikhson 4, 65029 Odessa, Ukraine \\ ${ }^{d}$ Odessa State Academy of Civil Engineering and Architecture, Department of Information Technologies and \\ Applied Mathematics, st. Didrikhson 4, 65029 Odessa, Ukraine \\ * corresponding author: irina.carpyuk@gmail.com
}

Abstract. Experimental data on the bearing capacity of damaged reinforced concrete beams with the dimensions of $2000 \times 200 \times 100 \mathrm{~mm}$, reinforced with prestressed metal casings, are presented. Damaging in the form of through normal and crossing inclined cracks, as well as excessive vertical moving of the beam were obtained during previous tests for the effect of high-level transverse alternating loads.

The authors of the article have developed a method and equipment for restoring and strengthening damaged reinforced concrete beams using a casing. Beams are manufactured and tested in accordance with the three-level design of an experiment.

Previously damaged and reduced to the ultimate (pre-emergency) state, the beams were strengthened with the declared method and equipment, and then retested. New data on the bearing capacity of ordinary and damaged beams, as well as reinforced concrete elements strengthened with casings and tested for the action of transverse forces and bending moments were obtained. The research results are presented in the form of experimental-statistical dependences of the bearing capacity of the support areas, deformability and crack resistance of the investigated elements on the ratio of the most significant design factors and external factors. A comparative analysis of the influence of these factors on the main parameters of the bearing capacity of ordinary as well as previously damaged and then strengthened test beams is carried out.

The possibility and appropriateness of using the proposed method of strengthening reinforced concrete beams damaged by through normal and cross-inclined force cracks in the conditions of an existing production has been experimentally proved.

KEYWORDS: Through normal and cross inclined cracks, reinforced concrete beam damaged by force cracks, prestressed metal casing, low-cycle alternating transverse load.

\section{INTRODUCTION}

Every day, engineers are facing new problems related to the increased seismicity of buildings and structures' siting, their physical wear and tear, changes of their functional purpose, increased load, etc. [1]. For this reason, from time to time, they have to solve complex technical problems related to the replacement or strengthening of damaged structures [2]. Replacing damaged reinforced concrete structures requires significant labour resources, financial costs and a long production stoppage. At the same time, the analysis of the damaged critically important reinforced concrete spans of a structure showed, in general, that during their operation, there are significant damages to the protective concrete layer, reinforcement corrosion, the appearance and excessive growth of cracks, unacceptable deflections, etc. [3, 4. Therefore, the authors [3, 4] recommend to strengthen them using well-known traditional methods and restore the bearing capacity.

Further experience has shown that the operation and service life of damaged structures can be extended by strengthening and renewing them during major repairs and without stopping the technological process [5].

Reinforced concrete structures can be reinforced with new reinforced concrete or reinforced mortars, which, in addition to increasing the weight and other known disadvantages, have the following disadvantages: the reinforcement system can usually work with a damaged element only after the materials have acquired the required strength in reinforced sections; lack of full control over the joint functioning of the damaged structure and the reinforcement system. 
Recently, the reinforcement of structures with glued composite materials has been increasingly used [6]. However, the high cost of such materials, the lack of direct control of reinforcement quality, the sensitivity to temperature effects, the possibility of a brittle fracture, and the imperfections of existing methods for their calculation hinder the possibility to use this progressive method of reinforcing damaged structures.

During their operation, most span reinforced concrete structures are exposed to cyclic or low-cycle repeated and alternating loads that occur within the operational level, and sometimes even exceed it. A load reversal, its level and indefinite repetition during the operation often lead to the consequences that are qualitatively different from those obtained when calculating for a constant load of one sign of maximum intensity, which is the focus of most of the current design standards. Strengthening of reinforced concrete beam structures damaged by through normal and inclined cross-open cracks, during the operation process carried to the limiting or pre-dangerous state, under the action of high-level growing cyclic load without stopping the production process using prestressed metal casing is uncontested. However, the design of such a reinforcement is controlled by the lack of a normative methodology and clear recommendations in the proprietary technologies, which adequately reflect the real stress-strain state of both the damaged structure and the reinforcement elements. This highlights the relevance of this work.

It was experimentally established [7] that low-cycle transverse alternating and intermittent load of high levels does not only reduce the bearing capacity of prototypes (reinforced concrete beams) to $20 \%$ and their crack resistance, but also significantly increases the width of the opening of normal cracks and, especially, oblique ones, the value of deflections up to $35 \%$, and also change the nature of their destruction in comparison with a one-time static loading of proportionally increasing load.

It is obvious that for strengthening reinforced concrete structures carried to the limit or danger states under such operating conditions, metal should be used as one of the most studied materials with stable strength and physical and chemical parameters that are easy to control.

One can strengthen the construction by setting additional reinforcement to the bare bearing rods of the stretched zone, its prestressing "concrete" and post-coating with concrete 8 . However, this method provides, firstly, the compression of the stretched zone, which leads to an increase in the resistance of this part of the structure without strengthening the rest of it. And, secondly, this method is unacceptable for alternating or seismic loads.

The method 9] deserves attention, as it provides for the fixing of the strengthening element in the compressed zone of the reinforced concrete beam and its further two-stage pre-compression before and after prestressing the strengthening element in the stretched zone.

However, this method allows to strengthen only normal sections of a solid reinforced concrete beam (without any cracks) subjected to only an intermittent transverse load or bending moment in the main vertical loading plane and does not lead to an increase in inclined sections and heel sections, in general, the intermittent load action. And with intermittent transverse loading (for example, during earthquake), this method, conversely, can lead to a premature destruction both along the pre-stretched upper elements of strengthening, normal sections, and along the crossed inclined sections. There are no recommendations for strengthening cracked reinforced concrete elements in the work 9 .

One of the first scientists in the Soviet Union, prof. V. V. Pinajyan [10], studied the possibility of using various equipment to strengthen the span reinforced concrete structures. In particular, he found that strengthening a damaged T-shaped reinforced concrete beam under the load with a reinforced mortar "jacket" increased its bearing capacity by $42 \%$, strengthening the same beam with prestressed longitudinal steel rods by $8 \%$, strengthening it using two devices described above at the same time by $71 \%$, and strengthening the beam only in the support areas with prestressed U-shaped clamps by $10 \%$. For a more reliable connection of an old concrete with the new one, the author [10] recommends installing additional metal ties to prevent their relative movement. He stated that the strengthening of the tensile zone of the structure with prestressed longitudinal reinforcement in the form of a truss rod is one of the most effective methods. However, in the paper [10], there are also no recommendations for strengthening damaged structures in a dangerous or pre-dangerous state, under the action of alternating cyclic loads.

This conclusion was confirmed by the tests [11 of reinforced concrete beams strengthened with prestressed metal tightenings, which showed a simultaneous increase in their bearing capacity and stiffness with raising the cross-section of the tightenings. The author's tests of strengthened two-span beams [11 showed that the prestressed tightenings turned the beams into an eccentrically compressed element, and also revealed the dependence of the redistribution of internal forces in the beam on the value of compressive forces from the tightenings. These tests also confirmed the prestressing feasibility in the vertical transverse bars. However, the author did not investigate the more complex three-dimensional stress state of reinforced concrete elements, damaged by throughthickness cracks [11].

A detailed qualification of the most common causes and conditions of building structures, which emphasizes the necessity for their strengthening as well as the methods of its implementation, is given in the publication [12]. It includes a complete set of various 
equipment for strengthening concrete structures, due to which this book has become the ultimate know-how source for many specialists in the field of reconstruction. However, the atlas of diagrams and drawings [12] still does not contain any equipment for strengthening dangerous structures for the action of a cyclic alternating increasing load.

The authors 13 proposed a design of equipment for strengthening a reinforced concrete beam with a metal sheet glued to its lower edge and pre-stressed horizontal elements in the form of two flexible tension bars on the side surfaces, where the stress is created by tightening (stressing) of the vertical elements anchored in the upper compressed zone. However, with the help of this structure, it is possible to strengthen only the lower tensioned zone and the support sections of the beam at a constant or intermittent cyclic transverse load.

Original equipment for strengthening bent building structures 14 contains a rigid wave-like strengthening element, stressed vertical stirrups, stressed reinforcement and support rollers. The strengthening element is attached at the ends and the points of contact with the strengthened bending structure from the side of the strengthened compressed zone. The longitudinal stressed reinforcement is fixed at the ends of the structure, which is strengthened, and the support rollers are between the stressed reinforcement and the stretched edge of the structure.

This equipment makes it possible to strengthen the upper compressed and lower tensile areas as well as partially supporting sections, as a result of which its bearing capacity increases, but under the action of a transverse load of only one direction.

It is interesting to strengthen reinforced concrete compressed and bent elements using steel sheets attached to their sides with a bolt connection [15]. In this work, the authors established the relationship between the bolted joint and the beam bearing capacity. Taking into account the cyclic nature of the load, the authors [16, 17] highlight the positive quality of the equipment operation and the plastic nature of the destruction of the strengthened structure.

Experimental studies 18 of a steel strip strengthening, glued onto an undamaged reinforced concrete beam, showed an increase of its bearing capacity by up to $300 \%$. At the same time, the authors [18] continue to study the end clamping of the tape in order to use its strength more and prevent brittle fractures of the beam.

The authors [19] tested four beams: the first one was not strengthened; the second one was strengthened with a glued steel strip at the lower part in the stretched zone; the third one was strengthened in the compressed and stretched zones with similar steel strips without gluing them to the body of the beam; the fourth one was strengthened with the same strips on the top and on the bottom, glued to the body of the beam using an epoxy glue. All the strengthened beams had the same ancho clamping of steel plates at their ends. The bearing capacity increased by $130-160 \%$ and the deformability of the beams strengthened with epoxy glue and the plastic nature of their destruction decreased.

Experimental studies [20] of three reinforced concrete beams, strengthened with steel plates located in the tension zone and fixed with end anchorages and epoxy glue, have shown an increase of load-bearing capacity by up to $48 \%$. And the publication [21] indicated that the use of a similar strengthening equipment (only with a different anchor design) resulted in bearing capacity increasing by only $10 \%$ as compared to a beam without any strengthening.

According to the results of experimental studies of a new strengthening equipment - an external rod roller-truss system of reinforced concrete beams, the authors 22] achieved an increase of bearing capacity by up to 4.5 times and a significant deformability decreasing.

At the moment of strengthening, the building structures are mainly under load, according to [23, the reliability of the strengthened concrete element depends on this value. As a result of the investigations of the stressed state of reinforced concrete beams, strengthened by lengthening of stretched reinforcement bars under the load action, the authors [24] proposed two new methods for assessing the reliability of reinforced concrete elements.

The article [25] presents the modernization of the truss analogy model in the design scheme of the support section of EC-2 beam, which includes two compressed concrete columns with a variable falling gradient, whose angles are determined using the equilibrium conditions and the theory of plasticity. At the same time, the upper compressed column, as a rule, has a lesser inclination as compared to the lower one. This is understandable, taking into account the shear stress increasing in the area of dangerous (critical) inclined cracks. The proposed model provides a better coincidence of the calculated values of shear strength with the experimental data under the action of a transverse load of the same direction, in comparison with EC2. However, the authors [25] do not indicate how to apply their original model for calculating reinforced concrete beams under alternating loads. So there are more elements that have received damage in the form of through normal and cross-inclined cracks.

In the publication [26], a conceptual model is proposed to predict the shear and flexural strength of thin reinforced concrete beams with and without any transverse reinforcement. The model takes into account the shear perceived by a compressed strip of uncracked concrete between the cracks, stirrups, if there are, and the longitudinal reinforcement. A physical explanation of the development of shear transfer mechanisms and the contribution of each factors to the bearing capacity of an element at the limit state are given. There are simple equations to check the shear strength 
and to calculate the shear reinforcement. The proposed model is confirmed by comparing its predictions with the results of shear testing of prototypes under the action of both concentrated forces and a uniformly distributed load. Considering the plane stress condition when determining the internal forces on the support section in the indicated beams, it is necessary to solve a statically indeterminate problem each time the number of unknown quantities (stresses in main and transverse reinforcement, normal and shearing stresses in concrete of a conditional compressed strip, its dimensions, projection length of a dangerous inclined crack, etc.) exceeds the number of possible equations of equilibrium and strain compatibility. Accordingly, the authors 26 highlight these issues with more details, and also describe their proposed design model for beams with any cross section under the action of an alternating transverse load.

The article 27] presents a model of a spatial truss with a variable angle, based on the theory of plasticity, taking into account the uneven distribution of longitudinal reinforcement along its sides. The proposed model is developed in stages: firstly, for a polygonal cross-section with an arbitrary number of sides, including arbitrary longitudinal reinforcement ratios and the corresponding slopes of concrete columns with an alternate angle, and then a simpler and more common case of a rectangular cross-section with two typical longitudinal reinforcement coefficients and two corresponding slopes of the columns with alternate angles. For practical design purposes, the results of this model are illustrated by normalized strength twisting curves of reinforced concrete elements, taking into account dimensionless reinforcement coefficients. The proposed model provides a good agreement between the calculation results and the experimental data of other authors. The operating experience of reinforced concrete frame elements shows that, in general, there are four internal stresses: bending, twisting, transverse and longitudinal moments. At the same time, bending moments and shear forces prevail in the parts of a flat framework. Therefore, the model [27] should be used for the general case of stressed state of a reinforced concrete element, with additional external reinforcement in the form of a prestressed casing.

There is also a practical interest in the article [28], which presents the results of experimental and numerical researches of L-shaped beams, made of lightweight aerated concrete LWFC, under a combined load. An experimental program was implemented that included tests of five L-shaped beams. A numerical model was also developed to simulate the stress-strain state of seventeen LWFC L-shaped beams. The effect on the breaking moment of the shear depth $(M / V d)$, the ratio of the twisting to the transverse force $(T / V d)$, the width of the flange to the side thickness $(B / b)$, and the coefficient of transverse reinforcement $\rho_{w}$ were studied. Under the combined loading of the elements with a large shear span $(M / V d>2)$, an increase in their strength was observed with a decrease in the $M / V d$ ratio and, conversely, a decrease of the bearing capacity by $67 \%$ with an increase in the $T / V d$ ratio. When testing prototypes with a small shear span $(M / V d<2)$, with an increase in the $T / V d$ ratio, their strength decreased by $28 \%$, and the nature of their destruction also changed. In addition, under combined loading, with increasing the relative width of the flange by 1.7 times, the breaking load increased by $24 \%$, and with increasing $\rho_{w}>1,2 \%$, the nature of samples' fracture changed from plastic to brittle. However, without an appropriate design of the experiment, the authors [28] did not have the possibility to study the mutual influence of the factors on the bearing capacity of these elements, which obviously took place. This limitation also applies to a variable load, during the study of the stress-strain state of L-shaped beams made of LWFC lightweight concrete with a combined load of the same direction. The scientific work 28 also does not have any recommendations for the calculation and strengthening of damaged structures if it is necessary.

From the review of publications, it can be concluded that in the national design standards and well-known proprietary technologies, there are no clear recommendations for calculating the combined action of span reinforced concrete structures, which are damaged, carried to the limit or in dangerous states, with elements of their strengthening.

The analysis of these publications showed that the existing methods of strengthening span reinforced concrete structures have the following common features:

- fixing strengthening elements on the damaged element;

- creating prestress in them in the longitudinal and vertical transverse directions.

The disadvantages of these methods and equipment for strengthening reinforced concrete beam structures are:

- strengthening, mainly, of normal (more often) and inclined (less often) sections of a solid reinforced concrete beam on the action of only constant transverse load in the main plane. Under the action of a variable transverse load, most of the existing methods and equipment can lead to a premature failure of the investigated elements;

- inability to restore or increase, if it is necessary, the bearing capacity of dangerous or carried-tothe-limit-state beam structures under the action of alternating cyclic or pulsating loads of high levels and seismic effects.

A comparison of the experimental data on the bearing capacity of concrete beams, both the ordinary and the ones strengthened with a metal casing, damaged by normal through and cross-inclined cracks under the action of a low-cycle alternating high level load with the calculation results using the existing 
proprietary technologies showed, in general, their unsatisfactory convergence for both the ordinary and the strengthened test beams. At the same time, the main part of publications is devoted to determining the bearing capacity of normal sections of ordinary and strengthened structures with metal elements according to the first and the second groups of limit states, while the strength of their inclined sections and bearing sections, in general, are still unstudied.

The purpose of this scientific work is an experimental and theoretical study of the bearing capacity, crack resistance and deformability of reinforced concrete beams, strengthened by prestressed metal casings, damaged by through normal and cross-inclined cracks under the action of a high-level low-cycle alternating load to improve the existing and to develop new physical and mathematical models of the bearing capacity of normal and inclined sections of damaged spans of reinforced concrete structures, strengthened with the indicated metal casings under the action of the described load.

Research objectives:

- to develop an original method of restoration and strengthening of reinforced concrete beams damaged by through normal and cross-inclined cracks and an equipment for its implementation;

- to study the stress-strain state, bearing capacity, the opening width of normal and inclined cracks, the deflections, the destruction nature of ordinary solid and concrete beams strengthened with prestressed metal casings, which were severely damaged and were almost destroyed during previous studies under the action of static and low-cycle high-level alternating load, using the designed experiment;

- to evaluate the influence of the main structural factors on the bearing capacity of the bearing sections of the studied ordinary and damaged reinforced concrete beams strengthened with prestressed metal casing, on their crack resistance and deformability using experimental-statistical dependences formed from the data of a full-scale experiment;

- to carry out a comparative analysis of the influence of the main design factors on the specified parameters of ordinary solid and damaged reinforced concrete beams strengthened with prestressed metal casings, taking into account the action of static and low-cycle alternating loads.

\section{TECHNIQUE OF EXPERIMENTS, MATERIALS AND EQUIPMENT}

In the Odessa State Academy of Civil Engineering and Architecture, complex experimental studies of the bearing capacity of the bearing sections of reinforced concrete span structures under complex stress state are being carried out [7, 29, 31].

To achieve this goal, the authors of the article have created a method and equipment 32 to restore and strengthen a reinforced concrete beam in a predangerous state due to its division by through normal and cross-inclined cracks (Figure 1) into separate blocks connected with each other by longitudinal and transverse reinforcement under the action of alternating cyclic or high-level pulsating load, as well as strengthening of an ordinary span reinforced concrete structure that, although being in a satisfactory technical condition, can reach the specified state under seismic effects. The task was solved by two inventions united by a single concept:

a) a method of restoring and strengthening a damaged reinforced concrete beam by fixing the strengthening elements on it with the subsequent creation of pre-stress in them and its three-sided (beam) compression;

b)an equipment for restoring and strengthening a damaged beam, which has longitudinal and transverse vertical and horizontal elements interconnected and pulled together by threaded couplings (Figure 2).

The following factors were variable at three levels in the experiment:

$x_{1}$ - the relative shear span (the distance from the support to the action line of the concentrated force), $a / h_{0}=1,2,3$ at $h_{0}=d=175 \mathrm{~mm}$;

$x_{2}$ - concrete grade C, MPa, C16/20, C30/35, $\mathrm{C} 40 / 50$;

$x_{3}$ - coefficient of transverse reinforcement: the outer metal casing $\rho_{f w}(\mathrm{~A} 240 \mathrm{C})=0,0046 ; 0,0105$; 0,0263 at $\rho_{s w}(\mathrm{BpI})=0,0016 ; 0,0029 ; 0,0044$ inside the beams;

$x_{4}$ - the level of transverse load in reinforced concrete beams of the first (ASD) and second series (A) $\eta_{1,2}$ $=0,5 ; 0,65 ; 0,8 \mathrm{u}$ prestressing level in the casing elements $\eta_{\sigma f}=0,25 ; 0,50 ; 0,75$ in the third series (D).

Coefficients of upper and lower longitudinal reinforcement $\rho_{l s}^{\prime}=\rho_{l s}=0,176$ for all the types of the beams. Coefficients of the upper and lower additional reinforcement of damaged reinforced concrete beams in the form of prestressed casing elements from the angle beams $25 \times 25 \times 4 \mathrm{~mm} \rho_{\text {ef }}^{\prime}=\rho_{e f}=0,0191$, at $l_{0}=9 h_{0} ; h_{0}=175 \mathrm{~mm}$ and $b=100 \mathrm{~mm}$ for ordinary reinforced concrete beams.

These factors can influence the characteristics of the stress-strain state nonlinearly. Therefore, it was reasonable to approximate the dependence of the last factors by polynomial experimental-statistical models of the second degree [33, 34, with $x_{i}$ normalized to non-dimensional $-1 \leq x_{i} \leq+1$. For this purpose, a 4 -factor $2^{\text {nd }}$ order 25 -point design of the experiment, namely the Box design (B4, close to D-optimal, [34, 35]) was carried out.

Each full-scale experiment of the first (ASD), second (A), and third (D) series was provided with two 


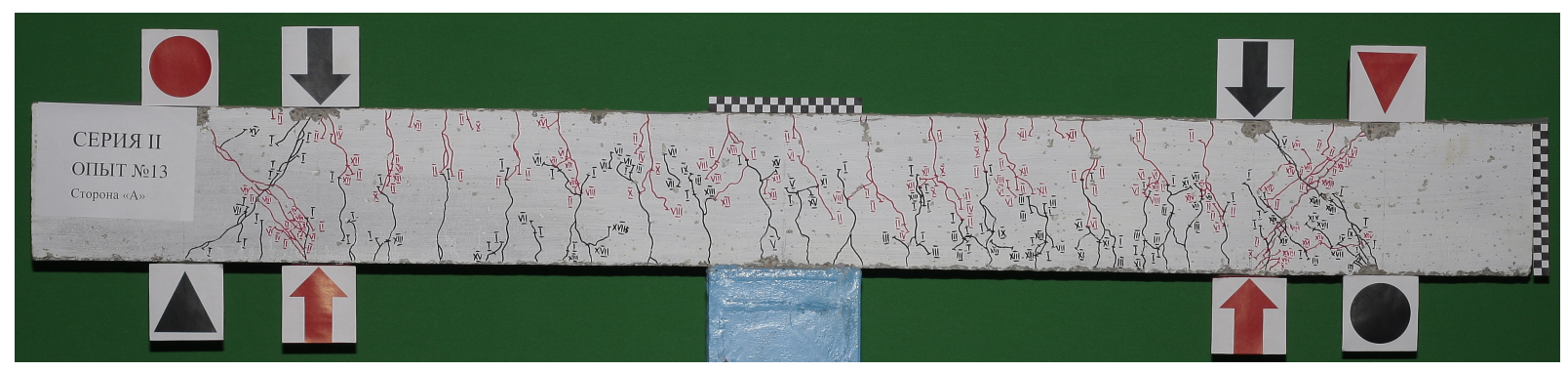

(A).

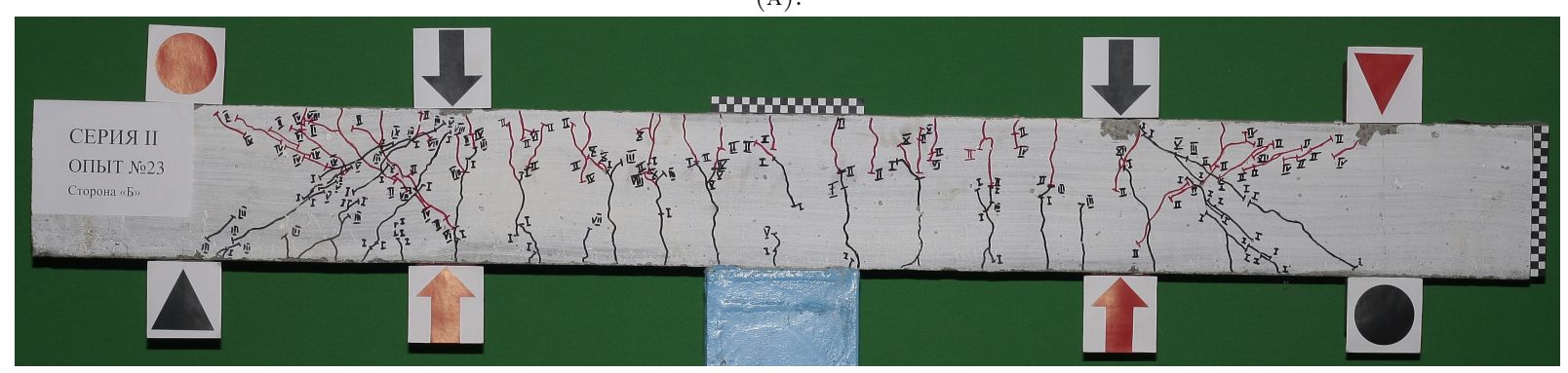

(B).

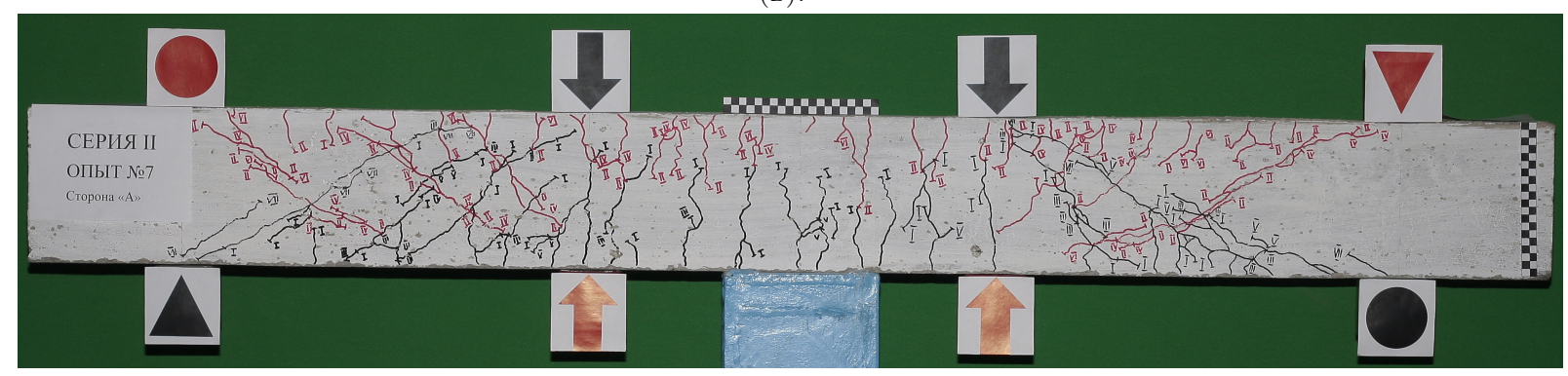

(C).

FigURE 1. Fixation of the formation and development of through normal and cross-inclined cracks in the experimental reinforced concrete beams with small (A), medium (B) and large (C) shear span.

twin-beams with four supporting sections. The prototype beams of the third series (D) were the same beams from the first series (A), which were damaged and divided into separate blocks by through normal and coss-inclined cracks (A), brought to the limit state during the previous tests of the effect of high-level alternating loads (Figure 1), and which in the third series (D), were restored and strengthened by the patented method and equipment 32 .

The prototypes - reinforced concrete beams - were reinforced with two flat welded frames. Heavy concrete of the above grades with granite crushed stone, with a fraction of $5-10 \mathrm{~mm}$, and quartz sand, with a fineness modulus of 1.5 , were used to make these elements. Portland cement, grade 500, without additives was used as a binder. To reduce the water-cement ratio in order to improve the workability of the concrete mixture and to shorten the concrete strength time, complex additive Relaxol-Super M (ISO 9001№04.156.26) at a $1 \%$ rate of the cement weight in terms of the dry substance was used in all the experiments.

To restore and strengthen reinforced concrete beams damaged by forceful cracks, special equipment was made for its implementation with this method, and a special power plant was certified for another ex- periments. The load was applied in cycles according to a four-point scheme using a DG-50 hydraulic jack and two spreader beams with two concentrated forces in steps: (0.04-0.06) $F_{\text {ult }}$ until the first normal and oblique cracks appeared, and then in the interval of (0,08-0.12) $F_{\text {ult }}$ until failure in the first series (ASD) or up to a given $\eta$ level of the alternating load in the first and other cycles, and subsequently, until the limit state or destruction in the final stage in the second (A) and the third (D) series. The load period was 15 minutes with all the measurements carried out at the beginning and at the end of each load step.

Monitoring the concrete deformations of the compressed area and tensile reinforcement, as well as the level of prestressing in the metal casing was carried out using dial indicators, and vertical displacements by Aistov's flexometer.

\section{BASIC MATERIAL AND RESULTS}

The test results of experimental reinforced concrete prototype-beams of the first (ASD) and second (A) series showed that their deformation, cracking and destruction occurred according to the rules of structural mechanics and were predictable. Normal cracks appeared first in the action area of maximum bending 


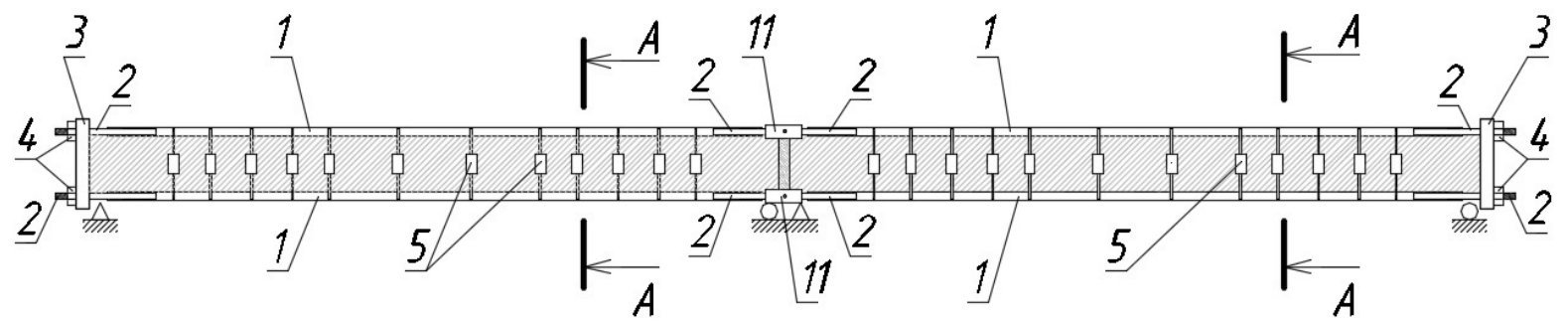

(A).

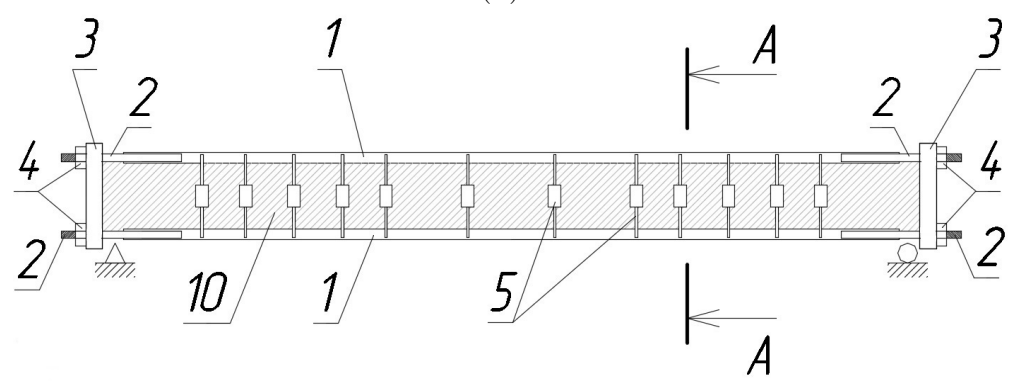

(в).

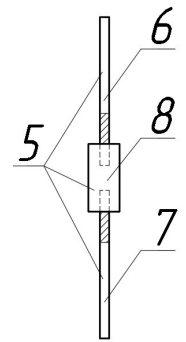

(c).

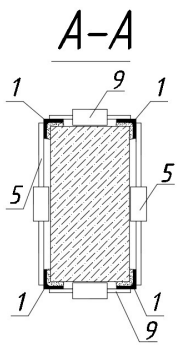

(D).

FIGURE 2. Metal prestressed casings for strengthening continuous (A) and ordinary single-span (B) damaged reinforced concrete beams; cross bar (clamp) (C) and cross-section of a reinforced beam (D)

1 - longitudinal horizontal strengthening element; 2, 6, 7 - threaded metal rod; 3 - supporting element; 4 - nut screw; 5 - transverse vertical strengthening element; 8 - threaded socket; 9 - transverse horizontal strengthening element; 10 - damaged beam; 11 - threaded socket.

moments. With further increasing the transverse load, the normal cracks developed into the depth of the beam, their opening width increased and new normal cracks appeared. Further increasing the static step load led to a further development of normal and inclined cracks with the predominant opening of inclined ones, and consequently to a beam fracture of the first (ASD) series along dangerous inclined cracks.

Prototype beams of the first (ASD) and second (A) series were designed to be of almost equal strength along normal and inclined sections, but so that their fracture would occur, nevertheless, along inclined sections at the final destructive stage of the shear load and related bending moments.

When the sign of the half-cycle of the beam load of the second (A) series changed, the previously formed normal and oblique cracks were completely closed under the action of compressive stresses in the previously extended (in the previous half-cycle) area. And vice versa, in the previously compressed area of "pure bending" in the next half-cycle, the new normal cracks appeared, which connected with the previous normal ones, forming visible through cracks. And in the bearing areas with the direction change of the half-cycle, new oblique cracks appear, crossing the previously formed oblique cracks at the angle of nearly $90^{\circ}$, which is explained by the direction of the main tensile stresses.

Increasing the levels of alternating load, the height of normal and the length of oblique dangerous cracks gradually increased, the bond between the concrete and the longitudinal and transverse reinforcement deteriorated, concrete decompaction occurred and its strength decreased, simultaneously, the crack opening width, deformability of prototype beams and relative movement of their individual blocks increased. The fracture of the beams of the second (A) series at high levels $\eta \geq 0,8 F_{\text {ult }}$ was, as a rule, fragile and mainly in the support areas.

The restoration and strengthening of the damaged beams in the second (A) series using the stated methods and devices [32] made it possible to align them, give them their original shape, and then significantly strengthen them. As a result, their bearing capacity significantly increased, which confirms the reasonability of applying the specified invention in practice. 
Strength (bearing capacity) of the investigated elements can be represented by the following experimental-statistical models:

$$
\begin{gathered}
\hat{Y}\left(V_{u 1}^{e x p}\right)=98-41 x_{1}+12 x_{2}+6 x_{3}+16 x_{1}^{2}-7 x_{2}^{2} \\
-5 x_{3}^{2}-7 x_{1} x_{2} \quad(\mathrm{kN}),
\end{gathered}
$$

the coefficient of variation $v=5.2 \% \quad$ (1)

$$
\begin{gathered}
\hat{Y}\left(V_{u 2}^{e x p}\right)=80-33 x_{1}+13 x_{2}+6 x_{3}-2 x_{4}+21 x_{1}^{2} \\
-12 x_{2}^{2}-5 x_{3}^{2}-7 x_{1} x_{2} \quad(\mathrm{kN}), \quad v=5.8 \%
\end{gathered}
$$

$$
\begin{aligned}
\hat{Y}\left(V_{u f}^{e x p}\right) & =148-32 x_{1}+17 x_{2}+2 x_{1}^{2}-8 x_{2}^{2} \\
& -10 x_{1} x_{2} \quad(\mathrm{kN}), \quad v=5.3 \%
\end{aligned}
$$

where $V_{u 1}^{e x p}, V_{u 2}^{e x p}$ - breaking shear force with statistical step-increasing and low-cycle alternating loads, respectively, in ordinary reinforced concrete beams according to [7];

$V_{u f}^{e x p}$ - breaking shear force of reinforced concrete beams of the second series (A) damaged by normal force cracks, strengthened with a prestressed metal casing according to 32, under the action of a lowcycle high-level alternating load at the values of design factors.

The presented adequate experimental-statistical dependences (1 3) allow to comprehensively evaluate both the individual influence of each factor on the studied output parameters and the effects of factors' interaction, and also compare the value of this influence on ordinary reinforced concrete beams under the action of a static step-increasing and low-cycle alternating high-level load and reinforced concrete beams strengthened with metal prestressed casing, damaged and separated by force cracks into separate blocks under the action of a similar load. The geometric interpretation of the bearing capacity of the supporting sections of the prototype beams can be partially shown in Figure 3

Among the design factors, the relative span size of the shear has the greatest influence on the bearing capacity of the bearing sections (Figure 3a). In general, the decreasing strength of inclined sections of reinforced concrete beam structures with increasing their shear span according to a nonlinear law, found in [36], and [29 31], is confirmed.

The next largest influence is the concrete grade. With increasing the grade from $\mathrm{C} 16 / 20$ to $\mathrm{C} 40 / 50$, the bearing capacity also increases according to a nonlinear law (Figure 3b).

A similar situation is observed with increasing the transverse reinforcement coefficient $\rho_{s w}$ (Figure 3c).
The influence of an increase in the level of transverse load $\eta$ from 0.5 to 0.8 turned out to be negative with its alternating character only for ordinary beams of the second (A) series (Figure 3d).

The analyses of dependencies 1,3 show that they are qualitatively the same type and the influence of design factors as well as the low-cycle load factor is qualitatively similar. The differences are in quantitative values.

Thus, the bearing capacity of inclined sections of prototype beams, expressed through the breaking shear force $V_{u}$, increases based on their average values - 98, 80 and $148 \mathrm{kN}$ :

- decreasing the relative shear span $a / h_{0}$ from 3 to 1 increased the bearing capacity of the first (ASD), second (A) and third (D) series by 84,83 and $43 \%$, respectively;

- increasing the concrete grade from C16/20 to C40/50 increased the bearing capacity by 24, 33 and $23 \%$, respectively;

- increasing the amount of transverse steel reinforcement $\rho_{s w}$ from 0.0016 to 0.0044 (1, 2) increased the bearing capacity by 12 and $15 \%$, respectively.

Increasing the number of prestressed transverse clamps of the metal casing $\rho_{f w}$ from 0.0046 to 0.0263 did not affect the value $V_{u f}^{e x p}$, apparently due to the effect of the combined work of all the prestressed elements of the metal casing and the previously damaged reinforced concrete beam, partially restored by a three-sided compression.

The change in the prestressing levels $\eta \sigma f$ in the case elements from 0.25 to 0.75 did not affect the strength of the support sections of previously damaged and then strengthened experimental beams with an alternating transverse load (Figure 3d).

Factors $x_{1}$ and $x_{2}$ significantly interact with each other. So, with simultaneously decreasing the value of the relative shear span $a / h_{0}$ and increasing the concrete grade $\mathrm{C}$, there is a noticeable $V_{u}$ increase. The presence of quadratic effects of the factors, $x_{1}^{2}$, $x_{2}^{2}$ and $x_{3}^{2}$, with the signs that are opposite to the direct influence of these factors, indicates that beyond the change in the studied factors $\left(a / h_{0}>3, \mathrm{C}>\right.$ $\left.40 / 50 \mathrm{MPa}, \rho_{s w}>0,0044\right)$, their further increase won't lead to significant changes in the bearing capacity of the prototype bearing sections.

An analysis of the obtained experimental data showed that low-cycle repeated loads reduce the bearing capacity of the bearing sections of reinforced concrete beams, on average, by $8 \%$, according to [31, and low-cycle alternating ones by $18 \%$, as compared to the bearing capacity of similar beams, tested for the action of a static, step-increasing load.

As illustrated in the field experimental studies, the bearing capacity of concrete beams damaged in previous experiments and strengthened with a prestressed metal casing 32, increased, on average, by $51 \%$, as compared to ordinary reinforced concrete beams of the 


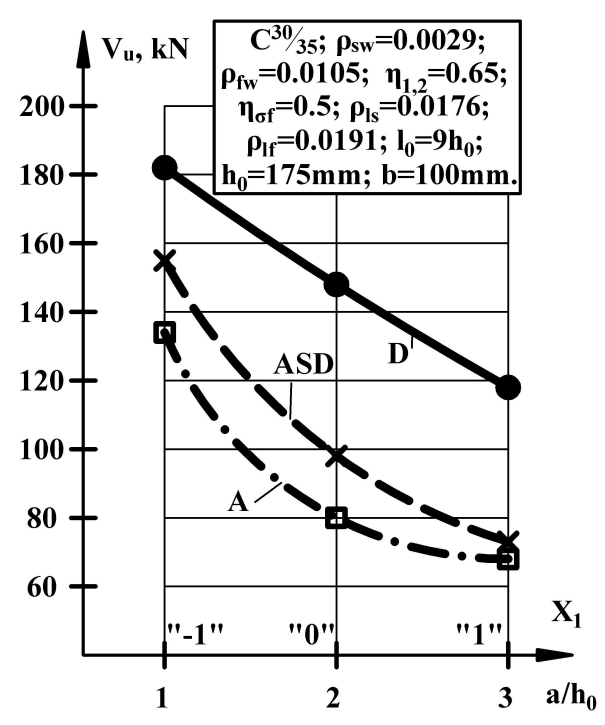

(A).

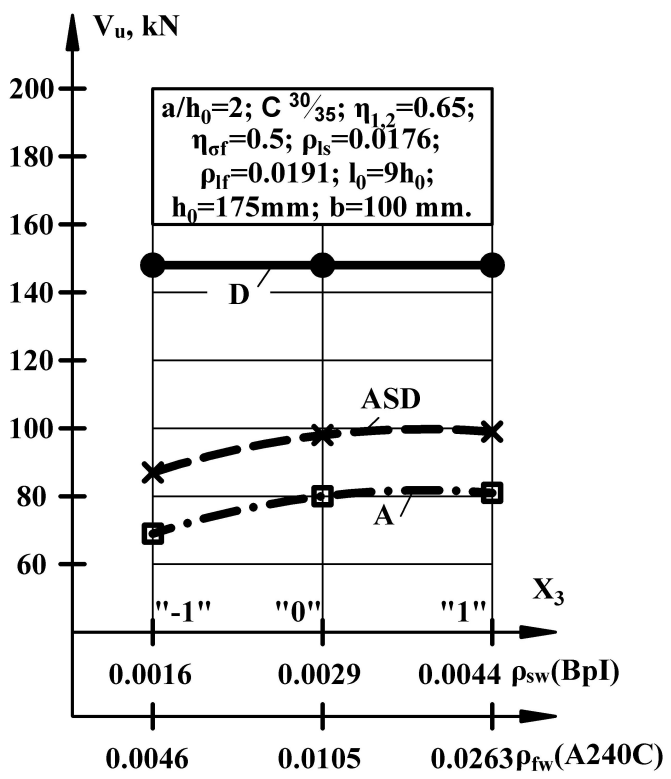

(c)

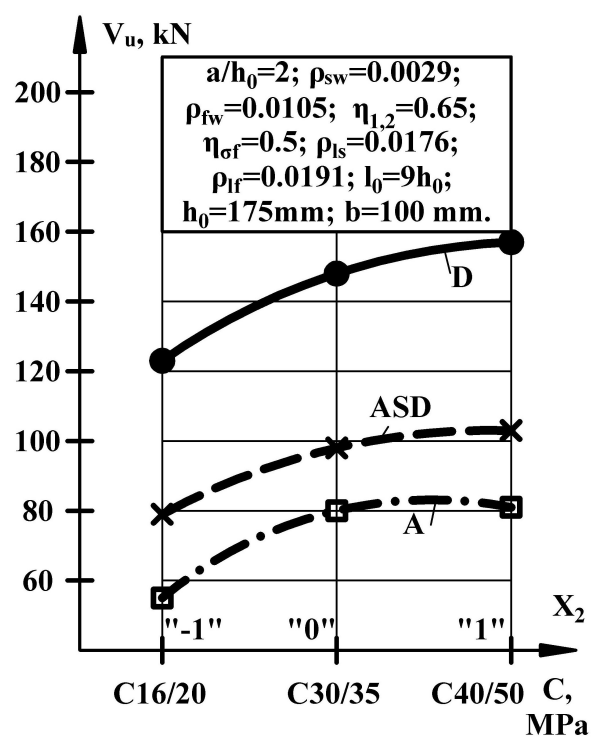

(в).

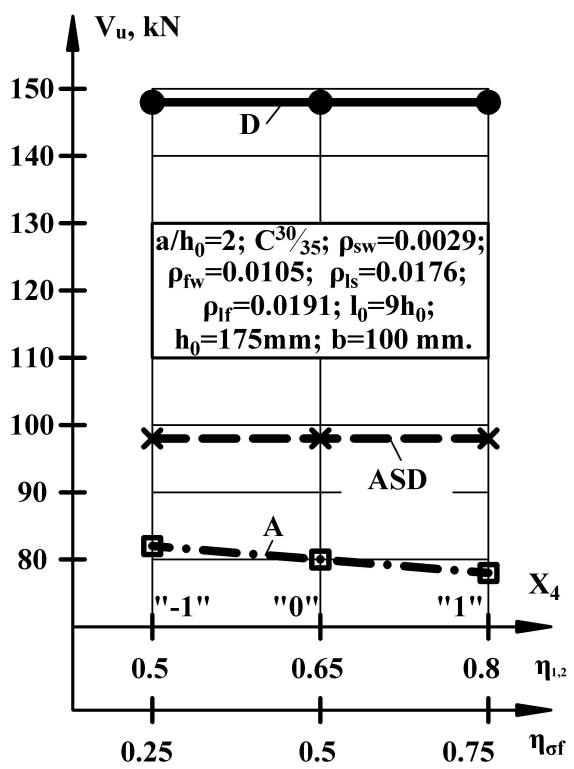

(D).

$\times--X$ ASD - experimental data of statically loaded reinforced concrete beams by K. Albu, D. Danilenko, Yu. Syomina [7];

口- - - $\mathrm{D}$ A - experimental data of cyclically loaded reinforced concrete beams by K. Albu [7];

D - experimental data of damaged reinforced concrete beams strengthened with a metal casing under cyclic loading by D. Danilenko [32].

FiguRE 3. Influence of the relative shear span (A), concrete grade (B), amount of transverse reinforcement (C), shear load levels and prestressing in the case members (D) on the bearing capacity of the bearing sections of the test members before their fracture. 
first series (ASD), which indicates the high efficiency of the reinforcement.

The vast majority of the test beams fractured along inclined sections in both or one (more often) shear spans. The destruction criterion of the prototypes was the achievement of ultimate deformations in the concrete or reinforcement with clear signs of plastic deformations in them, excessive opening (up to $1 \mathrm{~mm}$ or more) of oblique (more often) or normal (less often) cracks, a significant increasing of the sag of spans $\left(f \geq \frac{1}{100} l_{0}\right)$, no increase or some decline (up to $15 \%$ ) in the pressure gauge indications of the power plant pumping station.

It has been experimentally proven that the main reason for the decreasing bearing capacity of the prototype-beams under the action of low-cycle repeated and alternating loads is the structure rupture of the concrete, especially in the support areas, its decompaction and partial loss of its bond to the steel.

The greatest increase of permanent deformations in concrete and transverse reinforcement is observed in the first two or three cycles and, as a rule, it stabilized by the fifth or sixth cycle at load levels $\eta=0-0,65$.

The failure of reinforced beams of the third (D) series began with a gradual prestress loss in compressed case elements, opening of previously formed cracks, relative movement of individual blocks and excessive deformations of case elements, and ended with the fluidity of the reinforcement stretched in this cycle and a shape loss of the casing strengthening the supporting area.

The deflections of the investigated beams before their destruction can be characterized by the following experimental-statistical dependences:

$$
\begin{array}{r}
\hat{Y}\left(f_{u 1}^{e x p}\right)=6+1.5 x_{1}+0.65 x_{2}+0.7 x_{3}+0.35 x_{4} \\
-0.5 x_{1}^{2}+0.2 x_{1} x_{3} \quad(\mathrm{~mm}), \quad v=5.5 \%
\end{array}
$$

$$
\begin{array}{r}
\hat{Y}\left(f_{u 2}^{e x p}\right)=7.2+2.1 x_{1}+0.8 x_{2}+0.8 x_{3}+0.4 x_{4} \\
-0.5 x_{1}^{2} \quad(\mathrm{~mm}), \quad v=5.3 \%
\end{array}
$$

$$
\begin{gathered}
\hat{Y}\left(f_{u f}^{e x p}\right)=13.2+6.6 x_{1}-0.7 x_{2}+0.85 x_{3}-0.8 x_{4} \\
+1.5 x_{1}^{2}+0.4 x_{2}^{2}+0.6 x_{1} x_{3}-0.8 x_{1} x_{4}+0.9 x_{2} x_{4} \\
-0.6 x_{3} x_{4} \quad(\mathrm{~mm}), \quad v=5.1 \%
\end{gathered}
$$

which show that the vertical movement of the beams in the first (ASD) series of experiments, on average, were $(1 / 263)$ of the calculated span $l_{0}$, the second $(\mathrm{A})$ series $-(1 / 280) l_{0}$, and the third $(\mathrm{D})$ series $-(1 / 119)$ $l_{0}$ at this load. At the same time, the action of the low-cycle alternating load increased the deflections of the prototype-beams in comparison with a single statistical step-increasing load by $20 \%$.
The use of a prestressed metal case for strengthening beams damaged by low-cycle alternating load increased not only their bearing capacity by 1.85 times, but also deflections by the same amount. The graphic figure of deflections before the beam destruction and their dependence on the factors is illustrated in Figure 4

The opening width of normal cracks in the "pure bend" area can be represented by the dependencies 7 8 and in Figure 5 .

$$
\begin{gathered}
\hat{Y}\left(W_{c r 1,2}^{\perp \exp }\right)=0.14+0.02 x_{1}+0.03 x_{2}+0.01 x_{3} \\
+0.05 x_{4}+0.01 x_{1}^{2}-0.03 x_{2}^{2}+0.02 x_{4}^{2}+0.01 x_{1} x_{3} \\
+0.01 x_{1} x_{4}+0.02 x_{2} x_{4}+0.01 x_{3} x_{4} \\
(\mathrm{~mm}), \quad v=6.2 \%
\end{gathered}
$$

$$
\begin{array}{r}
\hat{Y}\left(W_{c r f}^{\perp e x p}\right)=0.06+0.04 x_{1}+0.02 x_{2}+0.01 x_{3} \\
-0.01 x_{4}+0.02 x_{1} x_{2}+0.02 x_{1} x_{3}-0.01 x_{1} x_{4}+0.01 x_{2} x_{3} \\
(\mathrm{~mm}), \quad v=21.6 \%
\end{array}
$$

As the expressions 7 and 8 show, the presence of the prestressed metal casing restrains the development of normal cracks in the middle of the beams and reduces the width of their opening, on average, by 2.3 times.

The opening width of inclined cracks in the bearing areas of the studied elements can be represented by experimental-statistical dependences and is shown in Figure 6

$$
\begin{gathered}
\hat{Y}\left(W_{c r 1}^{\prime e x p}\right)=0.35-0.06 x_{1}-0.03 x_{2}-0.01 x_{3}-0.14 x_{4} \\
-0.01 x_{1} x_{3}-0.03 x_{2} x_{4}-0.02 x_{3} x_{4} \\
(\mathrm{~mm}), \quad v=10.4 \% \quad(9)
\end{gathered}
$$

$$
\begin{gathered}
\hat{Y}\left(W_{c r 2}^{\text {exp }}\right)=0.63+0.05 x_{1}+0.05 x_{2}+0.06 x_{3}+0.24 x_{4} \\
-0.02 x_{2}^{2}+0.02 x_{3}^{2}+0.02 x_{4}^{2}+0.11 x_{1} x_{2}-0.03 x_{1} x_{3} \\
-0.06 x_{3} x_{4} \quad(\mathrm{~mm}), \quad v=11.5 \% \quad(10)
\end{gathered}
$$

$$
\begin{gathered}
\hat{Y}\left(W_{c r f}^{\text {exp }}\right)=0.50+0.20 x_{1}-0.01 x_{2}-0.05 x_{3}-0.09 x_{4} \\
+0.03 x_{1}^{2}-0.03 x_{1} x_{2}-0.04 x_{1} x_{4} \quad(\mathrm{~mm}), \quad v=8.4 \%
\end{gathered}
$$

An analysis of expressions 7, 8, 9, 10, and 11 shows that the opening width of inclined cracks in ordinary beams is 2.5 times greater than the opening width of normal cracks under a single static load. The action of low-cycle high-level alternating load increases the opening width of the inclined cracks by 4.5 times.

The use of a prestressed metal frame allowed not only to increase the bearing capacity of investigated 


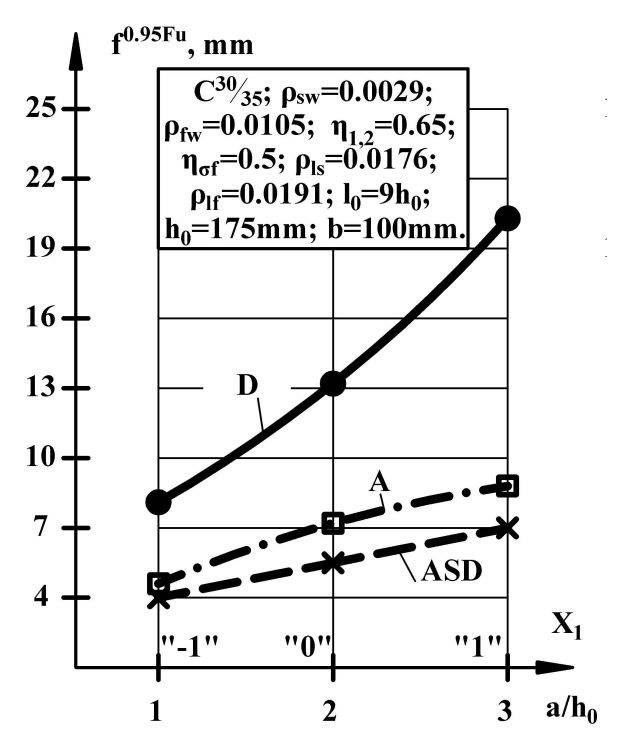

(A).

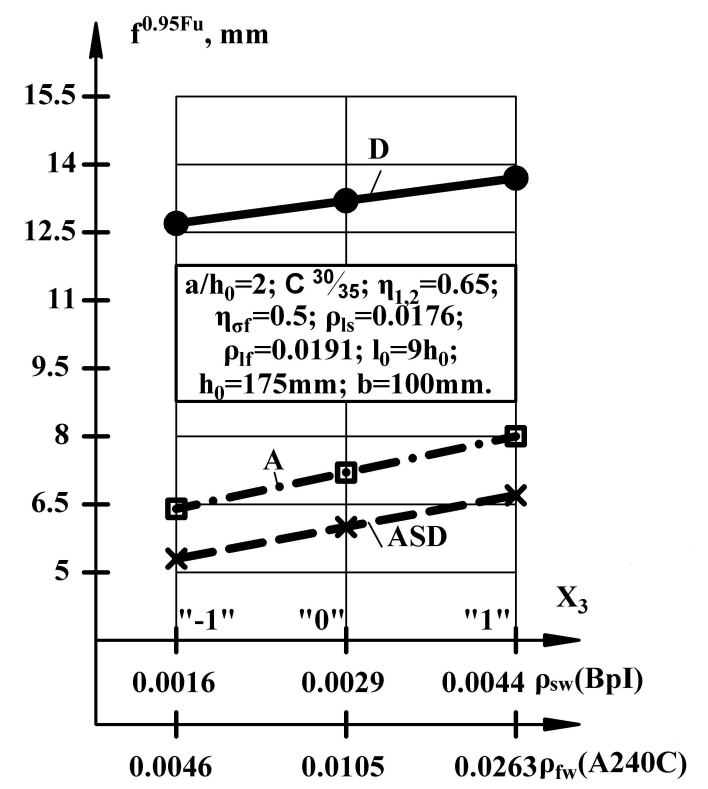

(C)

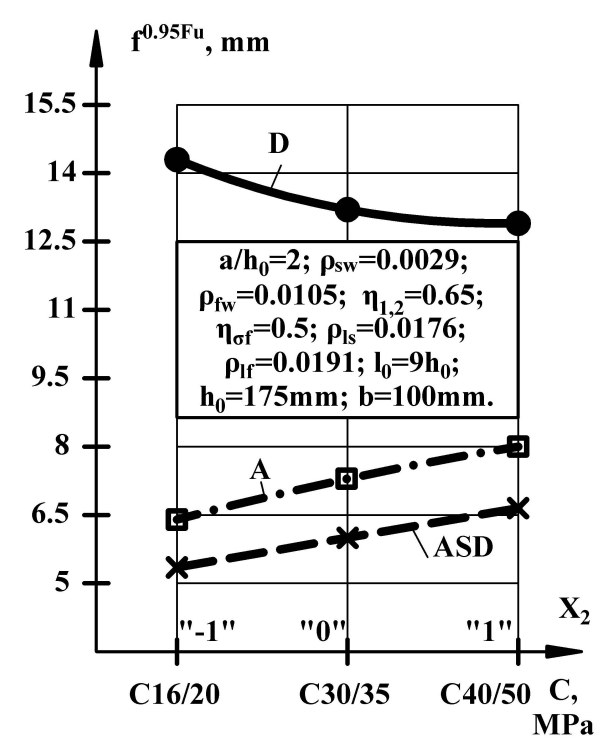

(в).

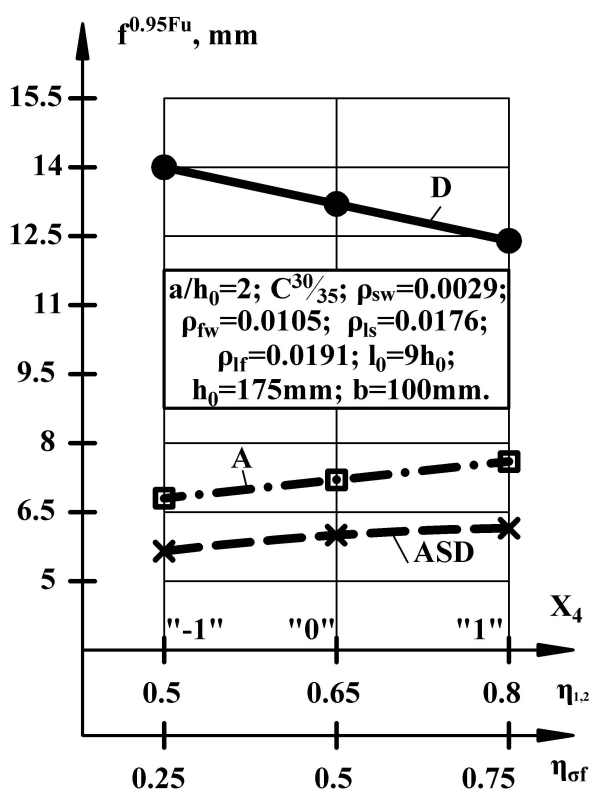

(D).

$\times--X$ ASD - experimental data of statically loaded reinforced concrete beams by K. Albu, D. Danilenko, Yu. Syomina [7];

口- - - $\mathrm{C}$ A - experimental data of cyclically loaded reinforced concrete beams by K. Albu [7];

$\mathrm{D}$ - experimental data of damaged reinforced concrete beams strengthened with a metal casing under cyclic loading by D. Danilenko [32].

FiguRE 4. Dependence of the deflections before the destruction of investigated beams on the value of the relative span of the shear (A), the grade of concrete (B), the amount of transverse reinforcement (C), the levels of transverse load, prestressing in the case elements (D). 


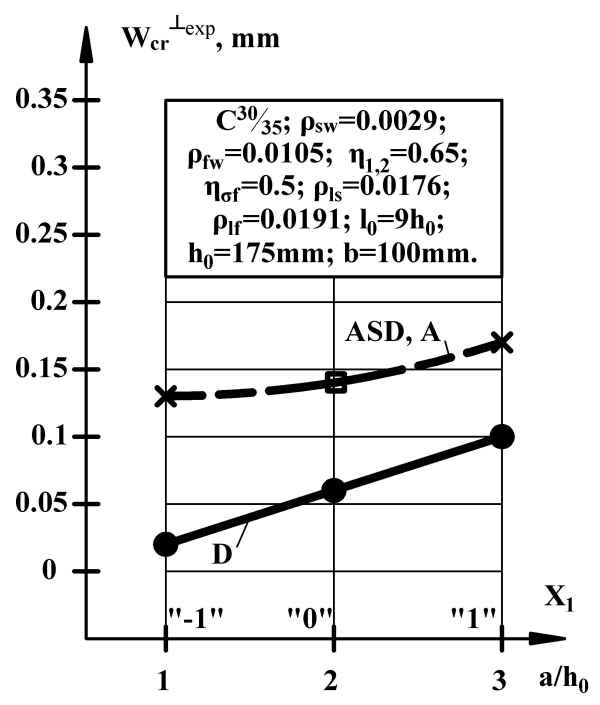

(A).

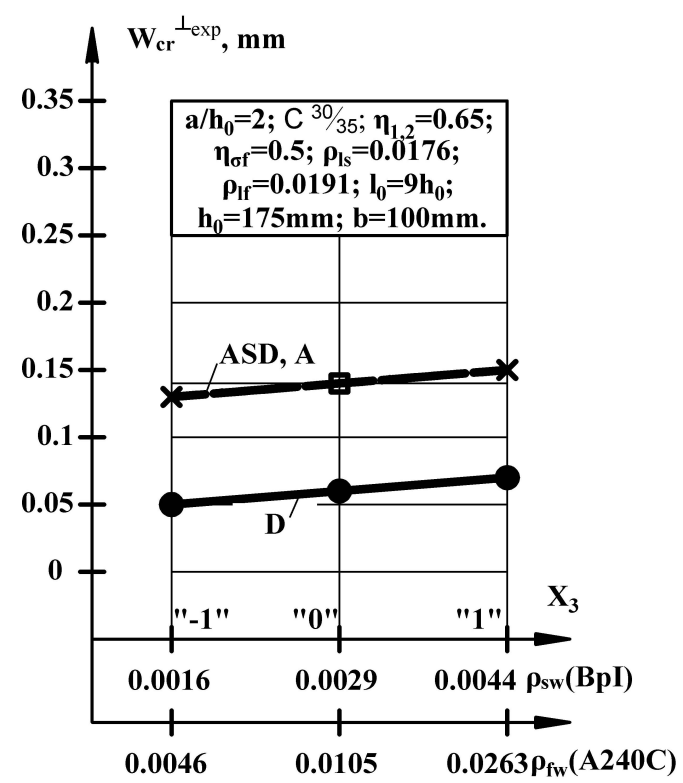

(c).

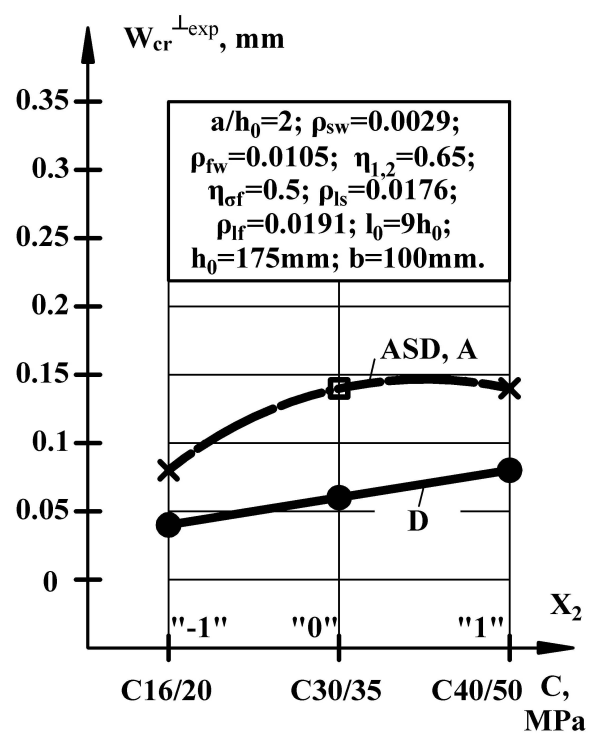

(в).

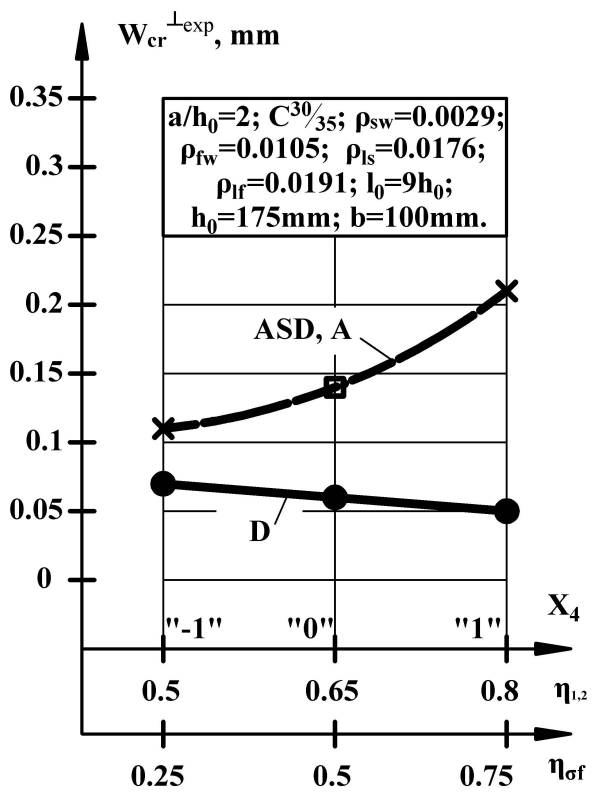

(D).

X - - X ASD - experimental data of statically loaded reinforced concrete beams by K. Albu, D. Danilenko, Yu. Syomina [7];

$\mathrm{A}-\mathrm{D}$ - experimental data of cyclically loaded reinforced concrete beams by K. Albu [7];
$\mathrm{D}$ - experimental data of damaged reinforced concrete beams strengthened with a metal casing under cyclic loading by D. Danilenko [32].

FiguRE 5. Influence of the relative shear span (A), concrete grade (B), the amount of transverse reinforcement (C), the levels of transverse load and prestressing in the case elements (D) on the opening width of normal cracks in the investigated elements before their destruction. 


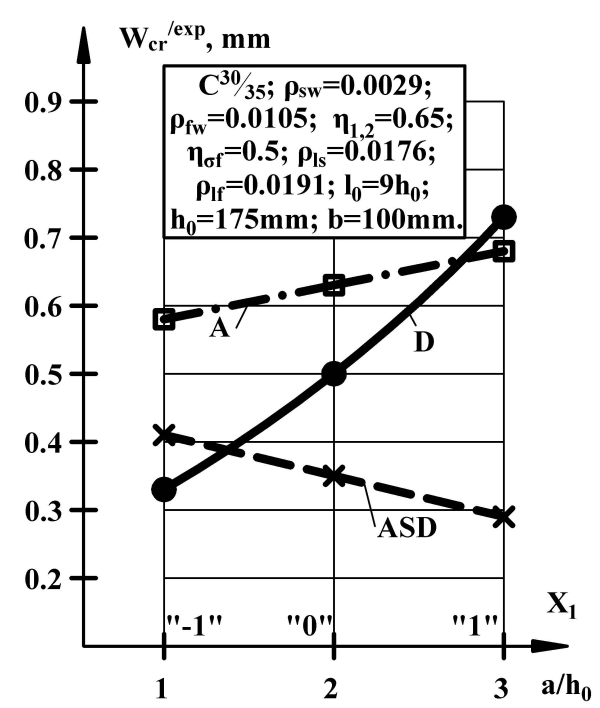

(A).

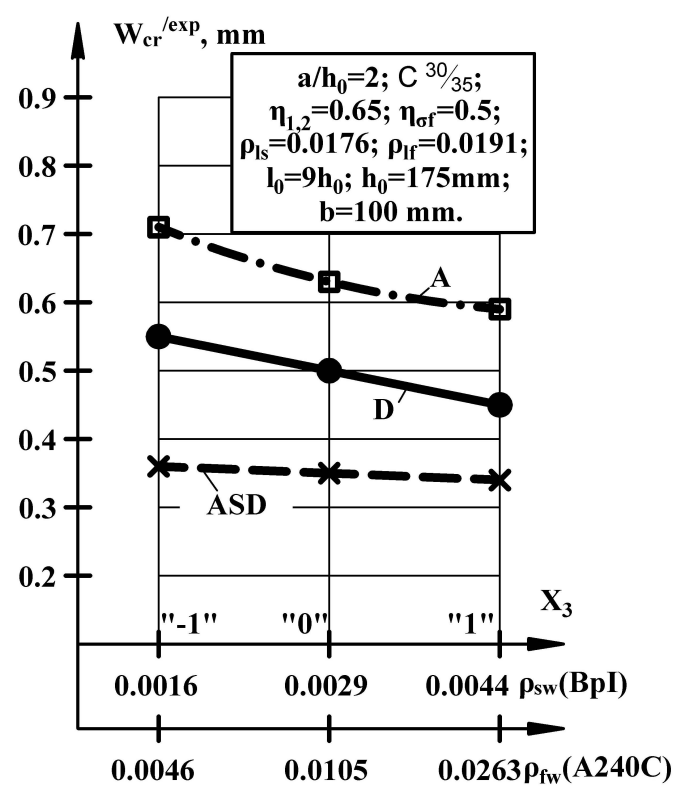

(C).

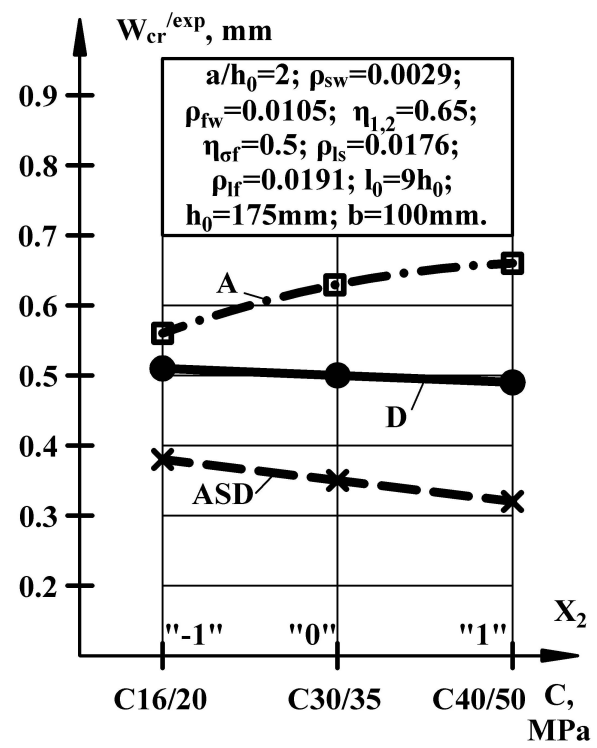

(в).

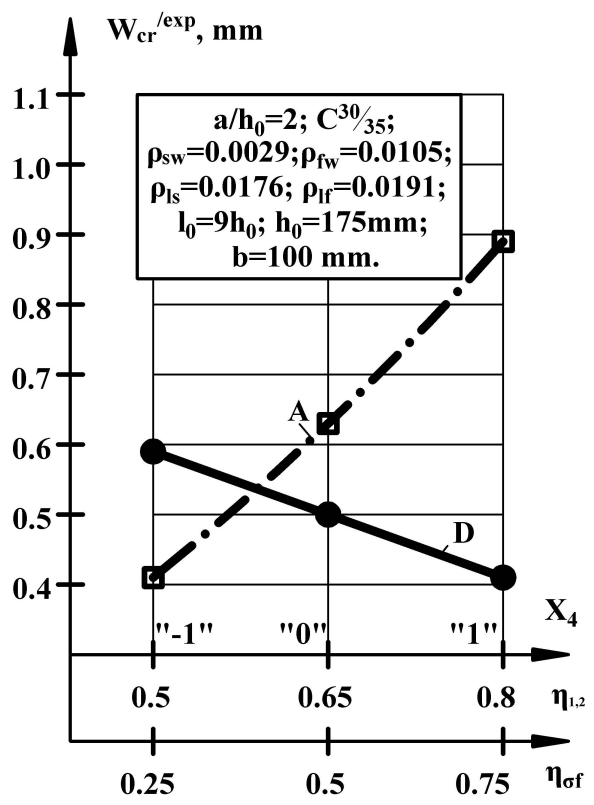

(D).

$\times \leftarrow-\times$ ASD - experimental data of statically loaded reinforced concrete beams by K. Albu, D. Danilenko, Yu. Syomina [7];

ㄴ - - $\mathrm{D}$ A - experimental data of cyclically loaded reinforced concrete beams by K. Albu [7];

$\mathrm{D}$ - experimental data of damaged reinforced concrete beams strengthened with a metal casing under cyclic loading by D. Danilenko [32].

FiguRE 6. Dependence of the opening width of inclined cracks before beam destruction on the size of the relative shear span (A), concrete grade (B), amount of transverse reinforcement (C), levels of transverse load and prestress in the casing members (D). 
beams, damaged and divided into separate blocks, by 1.85 , but also to reduce the opening width of inclined cracks by $21 \%$, which is another advantage of the applied strengthening method of damaged span structures.

The projection length of dangerous inclined cracks on the horizontal axis of the beam is represented by expressions 12,13 and is shown in Figure 7 .

$$
\begin{array}{r}
\hat{Y}\left(l_{c r l}^{\text {exp }}\right)=201+53 x_{1}-19 x_{3}-4 x_{1} x_{2}-23 x_{1} x_{3} \\
(\mathrm{~mm}), \quad v=8.5 \%
\end{array}
$$

$$
\begin{aligned}
& \hat{Y}\left(l_{c r 2, f}^{\prime \exp }\right)=173+40 x_{1}-16 x_{3}+19 x_{4}-16 x_{1} x_{2} \\
& -7 x_{1} x_{3}+14 x_{1} x_{4}-11 x_{3} x_{4} \quad(\mathrm{~mm}), \quad v=8.9 \%
\end{aligned}
$$

As the dependencies 12 and 13 show, the average length of the projection of a critical inclined crack under a low-cycle alternating load decreases in comparison with a static single load by $14 \%$ due to a fatigue failure of the concrete in the compressed area and the destruction of the protective layer of the concrete on the supports.

The distance between normal cracks in the "pure bend" area is characterized by the dependencies 14,15 and is shown in Figure 8

$$
\begin{array}{r}
\hat{Y}\left(l_{c r 1}^{\perp \perp \exp }\right)=68-6 x_{1}+2 x_{2}+3 x_{1} x_{3} \quad(\mathrm{~mm}), \\
v=5.1 \% \\
\hat{Y}\left(l_{c r 2, f}^{\perp \perp e x p}\right)=70.9-2.15 x_{1}+1.93 x_{2}-1.75 x_{3} \\
(\mathrm{~mm}), \quad v=4.7 \%
\end{array}
$$

Dependencies 14, 15 state that the average distance between normal cracks does not depend on the type of the load. At the same time, the influence of the relative shear span $a / h_{0}$ ( $X_{1}$ factor) has noticeably decreased with an alternating load.

In the available references, there are no experimental data on the bearing capacity of damaged reinforced concrete beams strengthened with a metal casing according to the proposed method [32]. The strengthening of damaged beams, divided into separate blocks by normal and crossed inclined cracks, is achieved by compressing them from three sides with prestressed elements.

In this work, a comprehensive analysis of the test results of ordinary reinforced concrete beams [7] under the action of a single static and low-cycle transverse alternating loading, as well as damaged beams strengthened with the indicated casing [32], under the action of the same load, is carried out.
The increase in bearing capacity and the decrease in deformability of span reinforced concrete structures strengthened by other methods are also noted in [15, 20, 22,24. Scientific works [15, 17, 37] deal with increasing crack resistance of reinforced elements.

As you can see, the results, obtained during the experimental study, do not contradict the usual ideas about the operation of reinforced concrete beams strengthened with metal elements, and, in general, confirm the effectiveness of the proposed reinforcement system.

\section{Conclusion}

(1.) The possibility and practicability of using the proposed method of restoration and strengthening reinforced concrete beam structures, which were damaged and divided into separate blocks by normal and crossed inclined cracks, with the use of three-sided compression and equipment for its implementation, secured by the patent for invention [32], under the action of increasing static, cyclic alternating, seismic, pulsating and other dynamic load, were experimentally proven.

(2.) The integrated approach to the experimental and theoretical study of the stress-strain state of ordinary, restored and strengthened span reinforced concrete structures damaged by through power cracks using prestressed metal casing, made it possible, for the first time, to make a reliable quantitative and qualitative assessment of the influence of structural factors and external factors on their bearing capacity, stiffness, crack resistance and other properties, both separately and in interaction with each other; essentially clarifying the physical model of the operation of these structures under static and low-cycle alternating loads. In particular, it was found that the bearing capacity of the investigated elements increases nonlinearly:

- decreasing the relative shear span $a / h_{0}$ from 3 to 1 in the indicated series ASD, A, D increased the bearing capacity by 84,83 and $43 \%$, respectively;

- increasing the concrete grade from C16/20 to C40/50 increased the bearing capacity by 24,33 and $23 \%$, respectively;

- increasing the amount of transverse steel reinforcement $\rho_{s w}$ from 0.0016 to 0.0044 (1) 2) increased the bearing capacity by 12 and $15 \%$, respectively;

- decreasing the level of low-cycle alternating load $\eta$ from 0.8 to 0.5 increased the bearing capacity by $5 \%$;

- decreasing the relative shear span $a / h_{0}$ and increasing the concrete grade $\mathrm{C}$.

(3.) A low-cycle repeated load reduces the bearing capacity of the bearing sections of ordinary reinforced concrete beams, on average, by $8 \%$ [31], and low-cycle alternating one by $18 \%[7$. 


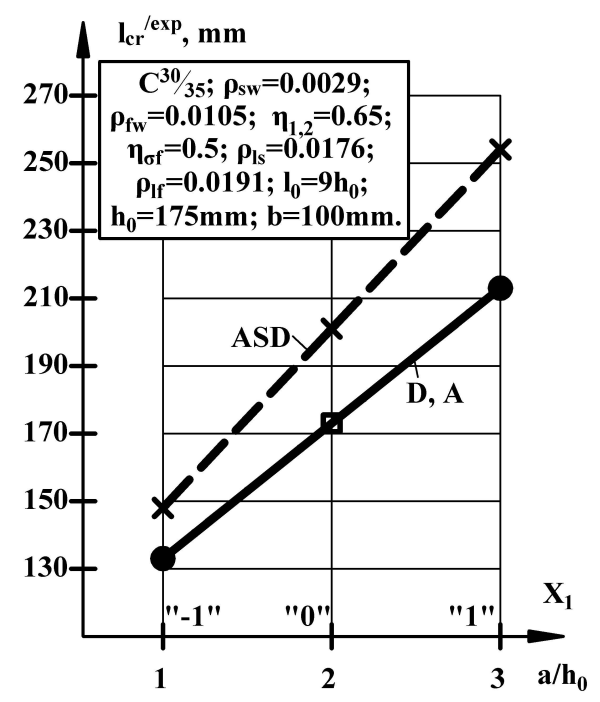

(A).

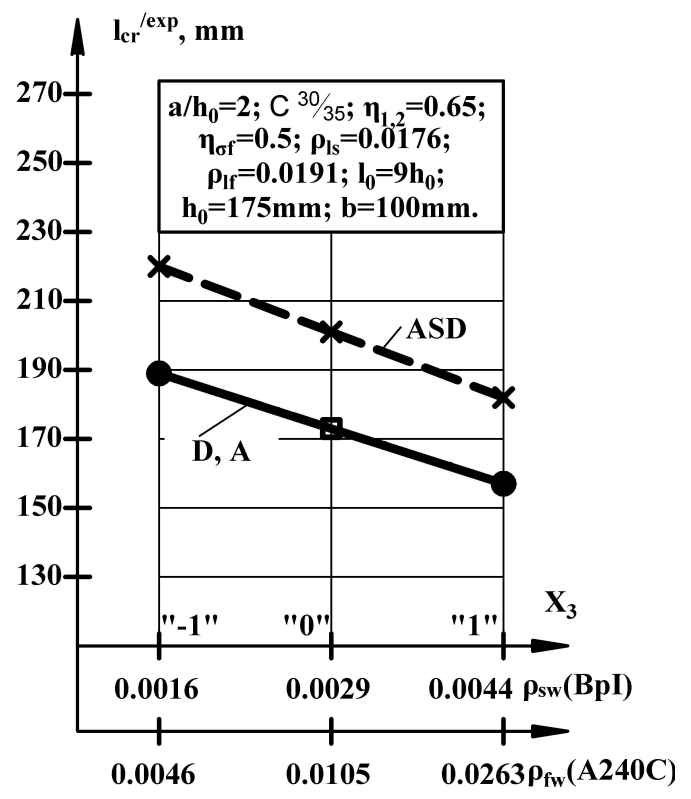

(c).

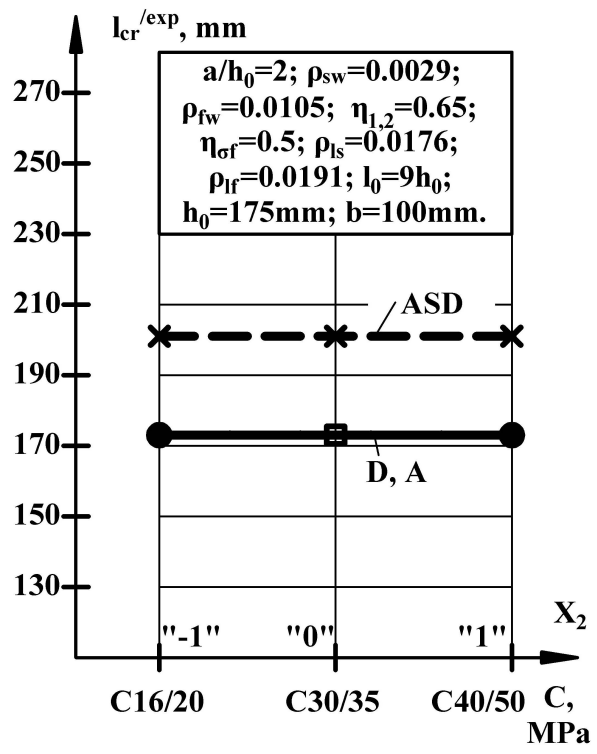

(в).

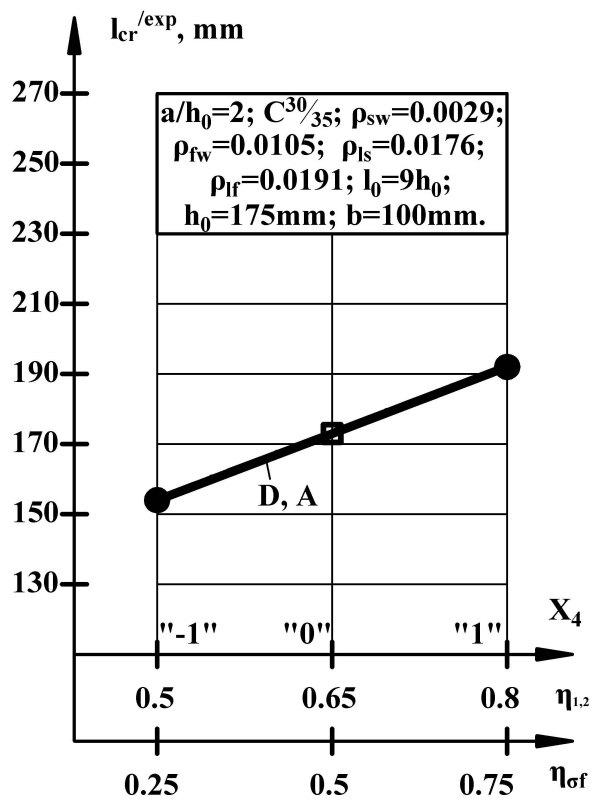

(D).

$\lessdot--\times$ ASD - experimental data of statically loaded reinforced concrete beams by K. Albu, D. Danilenko, Yu. Syomina [7];

口- - - $\mathrm{A}$ - experimental data of cyclically loaded reinforced concrete beams by K. Albu [7];

D - experimental data of damaged reinforced concrete beams strengthened with a metal casing under cyclic loading by D. Danilenko [32].

FigURE 7. Influence of the relative shear span (A), concrete grade (B), amount of transverse reinforcement (C) and levels of transverse load and prestress in the casing members (D) on the projection length of inclined cracks of the investigated elements before their destruction. 


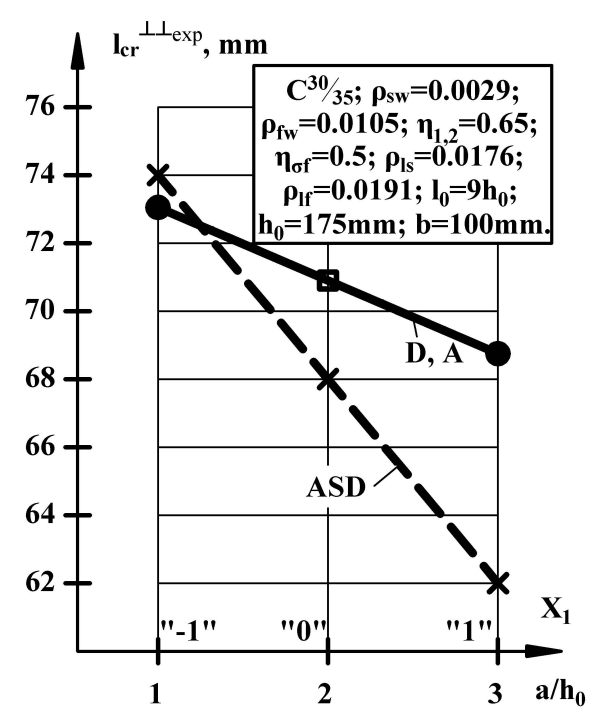

(A).

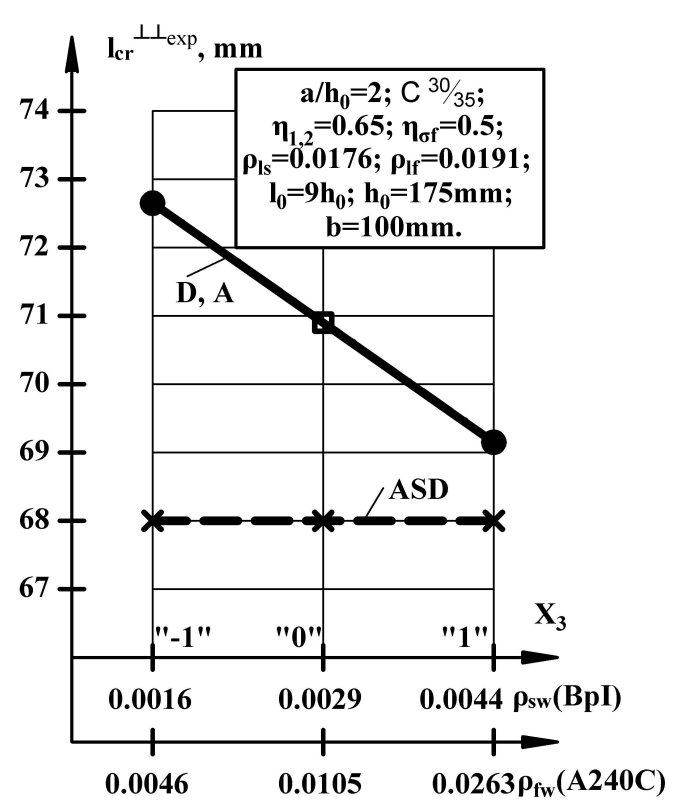

(c).

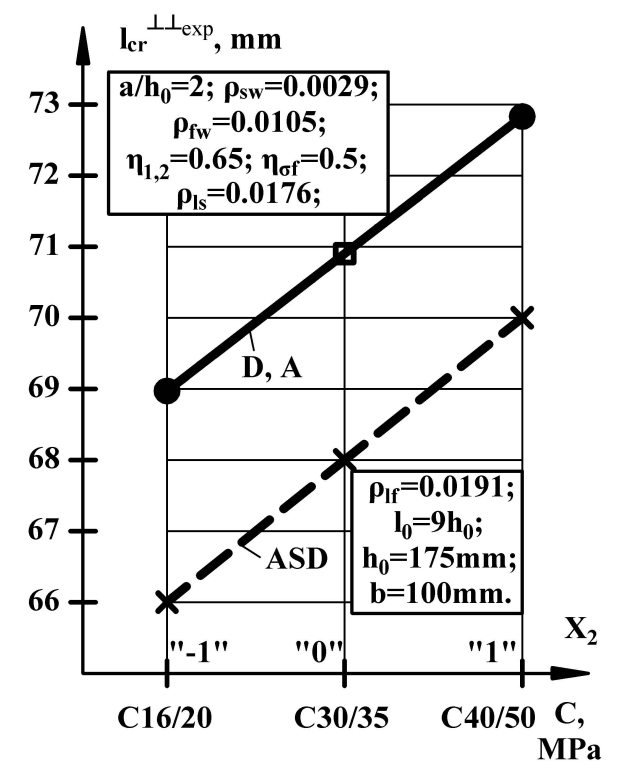

(B).

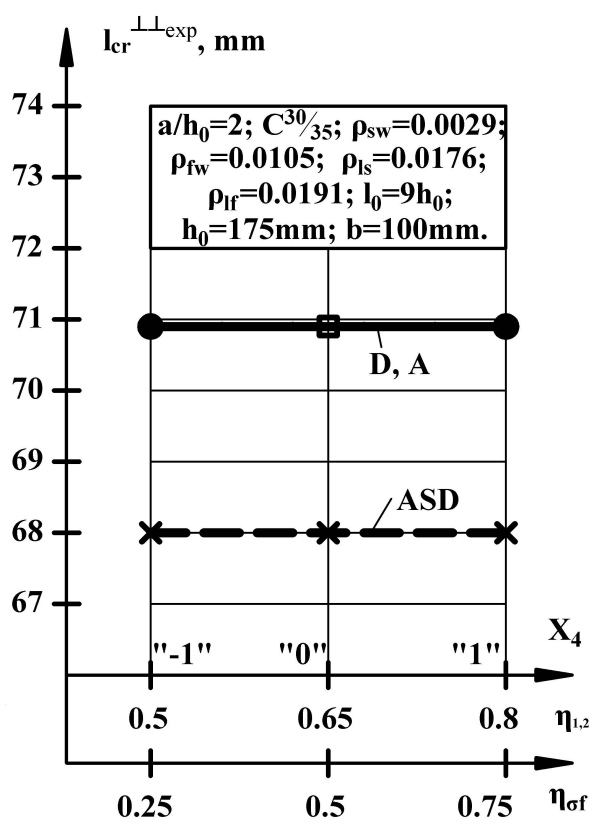

(D).

メ - - X ASD - experimental data of statically loaded reinforced concrete beams by K. Albu, D. Danilenko, Yu. Syomina [7];

- - - $\mathrm{D}$ A - experimental data of cyclically loaded reinforced concrete beams by K. Albu [7];

$\mathrm{D}$ - experimental data of damaged reinforced concrete beams strengthened with a metal casing under cyclic loading by D. Danilenko [32].

Figure 8. Dependence of the distance between normal cracks before the beam destruction on the value of the relative shear span (A), concrete grade (B), amount of transverse reinforcement (C), levels of transverse load and prestress in the casing members (D). 
(4.) The bearing capacity of damaged reinforced concrete beams strengthened with a prestressed metal casing 32, subjected to alternating load, increased, on average, by $51 \%$ as compared to ordinary reinforced concrete beams tested for a one-time static load, which indicates the high efficiency of the reinforcement.

(5.) The action of a low-cycle alternating load increases the deflections of the prototype-beams in comparison with the action of a one-time statically step-increasing load by $20 \%$.

The use of a prestressed metal frame to strengthen the damaged beams increases their bearing capacity and reduces their deflections by 1.85 times under low-cycle alternating load as compared to the same indicators for ordinary solid beams under a single static load.

(6.) The opening width of normal cracks in the middle of the investigated beams of all series does not exceed the permissible values and ranges from 0.02 to 0.22 .

The average value of an inclined crack opening at operational load levels in the test beams does not exceed the permissible values, and before the destruction, it fluctuates within the range of 0.35 to $0.63 \mathrm{~mm}$. At the same time, the use of a prestressed metal casing reduces the opening width of inclined cracks, on average, by $21 \%$, and normal ones by 2.3 times.

(7.) The average length of the horizontal projection of a critical inclined crack under a low-cycle alternating load decreases in comparison with static single loading by $14 \%$ due to the fatigue failure of the compressed area of concrete and softening of its protective layer on the supports.

\section{REFERENCES}

[1] A. Miano, G. Chiumiento. Case study on seismic retrofit and cost assessment for a school building. Structural Engineering and Mechanics 73(1):53-64, 2020. https://doi.org/10.12989/sem.2020.73.1.053

[2] B. Hu, H. L. Lv, T. Kundu. Experimental study on seismic behavior of reinforced concrete frame in primary and middle schools with different strengthening methods. Construction and Building Materials 217:473-486, 2019. https: //doi.org/10.1016/j.conbuildmat.2019.05.040

[3] P. Colajanni, A. Recupero, G. Ricciardi, N. Spinella. Failure by corrosion in PC bridges: A case history of a viaduct in Italy. International Journal of Structural Integrity 7(2):181-193, 2016. https://doi.org/10.1108/IJSI-09-2014-0046.

[4] H. W. Zhao, Y. L. Ding, S. Nagarajaiah, A. Q. Li. Behavior analysis and early warning of girder deflections of a steel-truss arch railway bridge under the effects of temperature and trains: Case study. Journal of Bridge Engineering 24(1), 2019. https: //doi.org/10.1061/(ASCE) BE.1943-5592.0001327
[5] M. Nishio, M. Abé. Operation of a damaged prestressed-concrete girder bridge with repair in Japan. Proceedings of the Institution of Civil Engineers Forensic Engineering 172(1):19-26, 2019. https://doi.org/10.1680/jfoen.18.00021.

[6] D. Shen, Q. Yang, C. Huang, et al. Tests on seismic performance of corroded reinforced concrete shear walls repaired with basalt fiber-reinforced polymers.

Construction and Building Materials 209:508-521, 2019. https:

//doi.org/10.1016/j.conbuildmat.2019.02.109

[7] V. Karpiuk, K. Albu, D. Danilenko, et al. Vpliv ciklichnogo znakozminnogo ta malociklovogo navantazhennya na micnist' zalizobetonnih balok [Influence of cyclic alternating and low cycle load on the strength of reinforced concrete beams]. In Visnik Odes'koï derzhavnoï akademï budivnictva ta arhitekturi, 58, pp. 103-119. 2015. http://mx.ogasa.org.ua/handle/123456789/2344.

[8] T. N. Azizov, D. V. Kochkarev, T. A. Galinska. New design concepts for strengthening of continuous reinforced-concrete beams. IOP Conference Series: Materials Science and Engineering 708:012040, 2019. https://doi.org/10.1088/1757-899X/708/1/012040

[9] R. Gabuzov, E. Aleksandryan. A. s. 1778250 SSSR, MKI3 E 04 V 1/00. Sposob usileniya konstrukcij [The method of reinforcing structures]. №4776410/33 ; zayavl. 03.01.90 ; opubl. 30.11.92, Byul. №44., https ://patents su/4-1778250-sposob-usileniya-konstrukcii.html

[10] V. Pinadzhyan. K voprosu usileniya izgibaemyh konstrukcij [On the issue of reinforcing flexible structures]. In Izvestiya Akademii nauk Armyanskoj SSR, pp. 79-108. 1947. http:

//www.flib.sci.am/eng/HSSR\%20GA\%20Texekagir\% 20Bnakan\%20gitutyunner/bgV9_47.html

[11] N. Onufriev. Usilenie zhelezobetonnyh konstrukcij promyshlennyh zdanij $i$ sooruzhenij [Reinforcement of reinforced concrete structures of industrial buildings and structures]. Strojizdat, Leningrad, 1965. https://dwg.ru/dnl/7364.

[12] A. Mal'ganov, V. Plevkov, F. Polishchuk. Vosstanovlenie $i$ usilenie stroitel'nyh konstrukcij avarijnyh $i$ rekonstruiruemyh zdanij. Atlas skhem $i$ chertezhej [Restoration and strengthening of building structures of emergency and reconstructed buildings. Atlas of diagrams and drawings]. Tomskij mezhotraslevoj CNTI, Tomsk, 1990. https://dwg.ru/dnl/4479

[13] E. Rabinovich, V. Blagov, A. Bohotskij. A.s. 1481359 SSSR, MKI3 E 04 G 23/02. Konstrukciya usileniya zhelezobetonnoj balki [Reinforced concrete beam reinforcement design]. №4248550/29-33; zayavl. 21.05.87 ; opubl. 23.05.89, Byul. №19., https://patents.su/?search=1481359\&type=number

[14] A. Luka, F. Kravchenya, A. Sobol. A.s. 1574771 SSSR, MKI3 E 04 G 23/02. Ustrojstvo dlya usileniya izgibaemyh stroitel'nyh konstrukcij [Device for reinforcing flexible building structures]. №4302639/2333 ; zayavl. 08.09.87 ; opubl. 30.06.90, Byul. №24., https://patents.su/?search=1574771\&type=number 
[15] R. K. L. Su, Y. Zhu. Experimental and numerical studies of external steel plate strengthened reinforced concrete coupling beams. Engineering Structures 27(10):1537-1550, 2005. https://doi.org/10.1016/j.engstruct.2005.04.012.

[16] U. Ebead, H. Marzouk. Strengthening of two-way slabs subjected to moment and cyclic loading. ACI Structural Journal 99(4):435-444, 2002. https://doi.org/10.14359/12112

[17] C. J. Jiang, Z. D. Lu, L. Z. Li. Shear performance of fire-damaged reinforced concrete beams repaired by a bolted side-plating technique. Journal of Structural Engineering 143(5), 2017. https: //doi.org/10.1061/(ASCE)ST.1943-541X.0001726

[18] V. Savjovs'kij, O. Molodid. Doslidzhennya osoblivostej pidsilennya zalizobetonnih balkovih konstrukcij zovnishnim armuvannyam [Investigation of reinforcement features of reinforced concrete beam structures by external reinforcement]. In Visnik Pridniprovs'koï derzhavnoï akademï budivnictva ta arhitekturi, 4, pp. 29-36. 2017. http://nbuv.gov.ua/UJRN/Vpabia_2017_4_5

[19] E. Ozbek, M. Bocek, S. Aycak. Strengthening of RC beams with solid steel plates. Athens Journal of Technology \& Engineering 3(4):291-298, 2016. https://doi.org/10.30958/ajte.3-4-1

[20] M. A. Alam, W. Mohammed, S. Bakkar, S. Beddu. Prevention of premature failures of plate bonded flexurally strengthened RC slab using end anchor and connector. Alexandria Engineering Journal $\mathbf{5 7}(1): 287-299,2018$. https://doi.org/10.1016/j.aej.2016.09.018

[21] H. Ying, P. Huawei, Q. Xueyou, et al. Performance of reinforced concrete beams retrofitted by a direct-shear anchorage retrofitting system. Procedia Engineering 210:132-140, 2017. https://doi.org/10.1016/j.proeng.2017.11.058.

[22] M. Chekanovich, V. Zhurahivs'kij, O. Chekanovich. Pidsilennya zalizobetonnih balok zovnishn'oyu strizhnevo-kotkovoyu sistemoyu [Reinforcement of reinforced concrete beams by an external rod-roller system]. In Resursoekonomichni materiali, konstrukcii ta sporudi : zbirnik naukovih prac', 36, pp. 413-420. 2018. https://doi.org/10.31713/budres.v0i36.293

[23] R. Khmil, R. Tytarenko, Y. Blikharskyy, P. Vegera. Development of the procedure for the estimation of reliability of reinforced concrete beams, strengthened by building up the stretched reinforcing bars under load. Eastern-European Journal of Enterprise Technologies $\mathbf{5}(7$ (95)):32-42, 2018. https://doi.org/10.15587/1729-4061.2018.142750

[24] R. Khmil, R. Tytarenko, Y. Blikharskyy, R. Vashkevych. Influence of load level during strengthening of reinforced concrete beams on their reliability. IOP Conference Series: Materials Science and Engineering 708:012054, 2019. https://doi.org/10.1088/1757-899x/708/1/012054

[25] D. De Domenico, G. Ricciardi. Shear strength of RC beams with stirrups using an improved Eurocode 2 truss model with two variable-inclination compression struts. Engineering Structures 198:109359, 2019. https://doi.org/10.1016/j.engstruct.2019.109359.

[26] A. Marí, J. Bairán, A. Cladera, et al. Shear-flexural strength mechanical model for the design and assessment of reinforced concrete beams. Structure and Infrastructure Engineering 11(11):1399-1419, 2015. https://doi.org/10.1080/15732479.2014.964735.

[27] D. De Domenico. Torsional strength of RC members using a plasticity-based variable-angle space truss model accounting for non-uniform longitudinal reinforcement. Engineering Structures 228:111540, 2021. https://doi.org/10.1016/j.engstruct.2020.111540.

[28] A. Deifalla, A. Awad, H. Seleem, A. Abdelrahman. Experimental and numerical investigation of the behavior of LWFC L-girders under combined torsion. Structures 26:362-377, 2020. http://repository.msa. edu.eg/xmlui/handle/123456789/3633?show=full.

[29] V. M. Karpiuk, Y. A. Somina, D. V. Antonova. Calculation models of the bearing capacity of span reinforced concrete structure support zones. Materials Science Forum 968:209-226, 2019. https://doi.org/ 10.4028/www.scientific.net/MSF.968.209

[30] V. Karpiuk, Y. Somina, O. Maistrenko. Engineering method of calculation of beam structures inclined sections based on the fatigue fracture model. In Proceedings of CEE 2019, vol. 47, pp. 135-144. Springer, 2020.

https://doi.org/10.1007/978-3-030-27011-7_17.

[31] V. Karpiuk, Y. Somina, A. Kostyuk, O. Maistrenko. Osoblivosti napruzhenno-deformovanogo stanu $i$ rozrahunku zalizobetonnih konstrukcij za dï ciklichnogo navantazhennya visokih rivniv: monografiya [Features of stress-strain state and calculation of reinforced concrete structures under the action of cyclic loading of high levels: monograph]. OSACEA, Odessa, 2018. http://mx.ogasa.org.ua/handle/123456789/7485.

[32] Sposib vidnovlennya ta pidsilennya poshkodzhenih zalizobetonnih balok i pristrij dlya jogo zdijsnennya [method of repairing and reinforcing damaged concrete beams and device for its implementation]. Pat. 119294 Ukraïna : MPK E04V 1/18, E04V 1/20, E04VG 23/02. № a 201800651 ; zayavl. 23.01.2018; opubl. 27.05.2019, Byul. №10, https://base.uipv.org/searchINV/ search .php?action=viewdetails\&IdClaim=258602.

[33] T. V. Lyashenko, V. A. Voznesensky. Applied Statistics in Industry Conf., chap. Experimental-statistical modeling in computational materials science, pp. 287298. $3^{\text {rd }}$ Int. ACG Press, Dallas, 1995. https://drive. google.com/file/d/0BzKYSjvwhyiecDl2enEta0dQc28/ view?resourcekey=0-Ub0434UsdynZ9DdvbslvGg.

[34] V. Voznesenskij. Statisticheskie metody planirovaniya eksperementa v tekhniko-ekonomicheskih issledovaniyah [Statistical Methods of Design of Experiment in Technical and Economic Studies. $2^{\text {nd }}$ ed. Finance and Statistics, Moscow, 1981. https://drive.google.com/ file/d/1vYr-AjJ3xbCk97cem6ARF7baULEUcj1W/view.

[35] D. C. Montgomery. Design and Analysis of Experiments. $10^{\text {th }}$ ed. John Wiley \& Sons, 2019. 
[36] A. Zalesov, Y. Klimov. Prochnost' zhelezobetonnyh konstrukcij pri dejstvii poperechnyh sil [Strength of reinforced concrete structures under the action of transverse forces]. Budivel'nik, Kiev, 1989.

http://books.totalarch.com/strength_of_ reinforced_concrete_structures_under_the action_of_transverse_forces
[37] T. Bobalo, Y. Blikharskyy, N. Kopiika, M. Volynets. Serviceability of rc beams reinforced with high strength rebar's and steel plate. In Proceedings of CEE 2019, vol. 47, p. 25-33. Springer, 2020.

https://doi.org/10.1007/978-3-030-27011-7_4 